DOI: $10.20472 / B M .2018 .6 .2 .004$

\title{
VALUE CHAIN MANAGEMENT IN AGRIBUSINESS
}

\section{GIULI KESHELASHVILI}

\begin{abstract}
:
Work offers discussion of the issues of value chain management and development in agribusiness. In particular, based on the study of business entities in Georgia it analyzes and assesses the process of value chain formation and role of the involved stakeholders that increase the product value for the consumers through organized cooperation.

Value chain connects the raw material producers, middlemen, processing enterprises, sales markets, service providers and different parties, whose activities promote competitiveness of one another at marketplace and its maintenance through introduction of innovations in the processes of value chain. Value chain management is the instrument of strategic business analysis and planning that is used for coordination of the value chain components and resources. Effective management of value chain directly affects profitability of the involved stakeholders and satisfaction of consumers. The work demonstrates the main challenges hindering development and effectiveness of agribusiness management in Georgia, including land fragmentation, low availability of advanced technologies, lack of business management awareness and skills, poor organization of logistics and supply process, low opportunities of negotiating and performing agrarian marketing etc.

Within the scopes of the research various cases of the agricultural cooperatives involved in the sector were studied and business cycles of priority sectors of Georgian agriculture were surveyed. Work was prepared on the basis of in-depth interviews with the industry experts, agribusiness managers and parties involved in the value chain. Secondary data (desk research) were collected through studying of the publications related to the issue and value chain reports.

Seasonality of raw materials production and their insufficiency was found to be one of the main causes of instability of value chain and supply chain in agriculture sector. Participants of value chain do not perceive one another as partners and do not care properly about the quality stability thus reducing competitiveness of their businesses.

In the process of research the emphasis was made on the problems of value chain management. In agribusiness, necessity of formation and setup of the full production chain allowing significant reduction of production costs was identified as one of the significant directions for production growth and development.

Recommendations offered by the work would contribute to improvement of value chain management in agribusiness, in Georgia.
\end{abstract}

\section{Keywords:}

value chain management, agribusiness, agricultural cooperative, production costs, supply chain, coordination.

JEL Classification: M10, M11, Q10

\section{Authors:}

GIULI KESHELASHVILI, Iv.Javakhishvili Tbilisi State University, Georgia, Email:

giuli.keshelashvili@tsu.ge 


\section{Citation:}

GIULI KESHELASHVILI (2018). Value Chain Management in Agribusiness. International Journal of Business and Management, Vol. VI(2), pp. 59-77., 10.20472/BM.2018.6.2.004 


\section{Introduction}

In Georgia, involvement of the population in agricultural activities has long history and traditions, comprising, on one hand, the country's strength and on the other - significant challenge for it, as the most part of the farmers manages production process based on the old machinery and technologies. As a result, their competitiveness is low at both, domestic and international markets and the process of economy management is more like the random set of poorly organized actions than the process planned in advance.

Significance of studying of the agriculture sector development and management issues can be clearly seen from its steadily low share in GDP that never grows irrespective of the costs made by the state and implemented large-scale projects, either nominally or actually.

For many years, diversity of the natural and economic conditions and variability of requirements have been impacting sector structure and development orientation of agriculture. For the past 20 years share of agriculture in GDP has decreased from $33.2 \%$ to $8.2 \%$. Land reform performed in 1992-1998 is regarded as one of the factors hindering development of agriculture and improvement of its competitiveness as it caused fragmentation of the large farms and naturalization of production. According to agriculture report of $2014,731 \%$ of the land users own land up to $1 \mathrm{ha}, 25.5 \%$ of them own land areas from 1 to 5 ha and only $1.5 \%$ own over 5 ha lands. The problem is further aggravated by the fact that owners of up to 1 ha land areas mostly own land as 2-3 parcels, while actually, development of profitable and economically powerful agriculture is impossible without consolidation of the lands.

Georgian agriculture development strategy for 2017-2020, approved by the government of Georgia states that cooperation is one of the key preconditions for agriculture development in Georgia. In the conditions of small household farms and fragmented lands, the farmer groups have the opportunity of improving competitiveness and profits of Georgian farmers and include them into the value chain.

Our research is intended to analyze the process of value chain management in agribusiness, identify the challenges and develop recommendations for improvement of the process effectiveness and thus contribute to improvement of the results of the parties engaged in the specific sectors. In the research process the means for improvement of the farms profitability and life standards through effective management of the agriculture products value chain.

We have used as one of the key research instruments in-depth interviews with all participants of value chain: farmers, middlemen, distribution companies, processing enterprises, exporters, agricultural product stores etc. 


\section{Foreign Experience of Agricultural Cooperatives' Management}

Examples of the successful cooperatives in the world's leading countries provide interesting information for practical generalization of their experience in Georgia. Study and sharing of the international experience is decisive for improvement of the agriculture cooperatives' management effectiveness. For this research we selected the countries that provide an example of successful reforms for us. In these countries the legal regulations for the cooperatives are based on the constitution, civil, administrative, cooperatives', banking and tax legislations. For example, in Germany, the cooperative activities are based on German Federal Law Commercial and Economic Partnerships adopted in 1889; in Great Britain - on the Law on Industrial Associations and Benefit Societies. In Portugal, the basis of legislation dealing with the cooperatives is the Cooperative Code. Here the cooperatives are the legal entities with special legal status that imply certain tax exemptions for the cooperatives. Support activities from the state are provided by the cooperatives development program. In Japan there are different legal regulations for the agricultural cooperatives and consumers' cooperatives. Legal regulations for the agricultural cooperatives are provided in the Law on Agricultural Cooperation (1947). Here, the agricultural cooperatives imply production, marketing, and procurement of the production factors, consultations, credit and insurance cooperatives. $90 \%$ of Japanese farmers are members of the agricultural cooperatives. Legal regulations of the consumer cooperatives are provided in the Law of Japan on Consumer Cooperation (1948), In Italy, the legal status of the cooperatives are determined by the different laws, e.g. Article 45 of the Constitution, stating that the "Republic recognizes social function of the cooperation". Cooperation purposes are formulated in the Civil Code of Italy specifying that the goal of cooperation is providing for its members services and work conditions better than those at free market. In Ukraine all legal entities are classified as the entrepreneurial and non-entrepreneurial societies. The production cooperatives are recognized as the entrepreneurial societies and the consumer cooperatives - as the nonentrepreneurial cooperatives. Legal status of the non-entrepreneurial society is determined by the Civil Code of Ukraine. In Denmark and Belgium there are no legal acts regulating the cooperatives' activities and the key legal acts that would regulate their operation. Here the cooperatives' activities are regulated by the internal normative acts developed by the cooperatives. In these countries the cooperative movement is at quite high level. For example, in Denmark, starch producing cooperative unifies over 3000 farmers, with 5 enterprises, producing 170000 tons of potato starch per year. $85 \%$ of their products are exported and sold in over 40 countries.

According to the world experience, the most important benefits for the cooperative members resulting from cooperation include availability of the equipment, plants and machinery, market and information; improvement of availability of the specialization and distribution of work. There are two types of agricultural cooperatives: production 
cooperatives and service cooperatives. In the production cooperatives the members jointly produce the goods; they have production factors in joint ownership (land, buildings and structures, equipment; mechanization etc.) and jointly use them. Economic activities of the production cooperatives are based on the consolidated production factors. In the opinion of some scientists, this provides certain advantages compared with small individual farms. Researches in the countries with market economy show that we have no economy of scale at the level of initial agricultural production. Moreover, in many cases it turns out that the production cooperatives are less effective than individual farm economies. This is also confirmed by the fact that, according to International Cooperatives Alliance (ICA) data, share of the production cooperatives in global cooperation system is no more than $5 \%{ }^{1}$. Service cooperatives are most widespread form of cooperatives in the world. In the associations of this type the cooperative members do not consolidate the property and production factors. The cooperative allows its members procurement of the production assets at relatively low prices (if before unification, they, individually, provided the retail demand, after unification they create the wholesale demand); consolidate the products, process them and sell jointly; provide joint marketing; receive industry and other consultations. Share of the service cooperatives in the agricultural transactions in the developed countries is highest, comprising, for example, $30 \%$ in USA, $50 \%$ in EU and almost $85 \%$ in Japan ${ }^{2}$.

\section{Analysis of Agricultural Cooperatives' Management in Georgia}

Poorly conceived land reform in 90 s of the $20^{\text {th }}$ century resulted in excessive fracturing of the lands in Georgia. Over $90 \%$ of the population owns the agricultural parcels up to 2 hectares only and work on such land parcels is ineffective. For the purpose of dealing with this problem and helping small farmer the extensive work for creation of the agricultural cooperatives have commenced. With respect of the state policies dealing with the cooperatives significant steps were made in 2013, when the Agency for Development of Agriculture Cooperatives was established. In the same period Georgian Law on Agricultural Cooperatives was approved. Significant institutional basis was created to support development of the cooperatives.

Georgian Law on Agricultural Cooperatives set the organizational norms for establishment and operation of the agricultural cooperatives. This Law has certain advantages compared with Georgian Law on Entrepreneurs regulating relations with the enterprises of all types of organizational-legal forms. Georgian Law on Agricultural Cooperatives regulates such issues as: key principles of the agricultural cooperatives' founding, democratic management, goals of the agricultural cooperatives, spheres of activities of agricultural cooperatives, functions of the Agriculture Agency, award and

\footnotetext{
1 International Co-operative Alliance, https://ica.coop/

2 International Co-operative Alliance, https://ica.coop/
} 
termination of the agricultural cooperative status, monitoring of the cooperatives' operation, cooperative membership, the members rights and obligations, rules of making contributions by the members, types of shares, distribution of profits of the agricultural cooperatives etc. In addition to the mentioned law, the organizational structure of agricultural cooperative and internal production relations are regulated by the cooperative's charter and agreement made between the cooperative and its member.

The cooperative is based on the principles of voluntary membership, dedication to business, leadership, sound and effective management. Modern cooperative allows the small farmers building his/her business based on the democratic principles. In our country, membership of agricultural cooperative is voluntary, its management is provided according to the democratic principles: all members are equal, irrespective of the size of contribution, whether it is 100 ha or 1 ha agricultural land.

In all cases each member has one vote. The key principles of the cooperative's operation are as follows: voluntary membership; democratic management; economic participation of members; social responsibility, fairness and mutual assistance.

Cooperative management is provided by the management and control bodies elected at the general meeting. Management bodies include the supervisory board, representatives' meeting and management board while the control body is the revision commission. Cooperative members control functioning of the management bodies at all levels of production activities. Democratic form of management allow the cooperative protecting and maintaining its identity, qualities and values thus making it substantially different from the enterprises of other organizational-legal forms. Economic participation is determined by the agricultural goods produced and delivered by the member within the scopes of agricultural activities or share of the delivered services. "Economic participation" shows the member's function of being directly involved in the activities of cooperative. Unlike the Law on Entrepreneurs, where the cooperative members are entitled to the dividends proportional to their contributions, according to the Law on Agricultural Cooperatives, the member is entitled to the dividend proportional to his/her economic participation.

Monitoring of the agricultural cooperatives is provided by the Legal Entity of Public Law, Agricultural Cooperatives Development Agency (ACDA) subordinated to the Ministry of Agriculture of Georgia. The Agency examines compliance of the cooperative's activities with the requirements of Georgian Law on Agricultural Cooperatives by means of scheduled and unscheduled monitoring activities. In case of the scheduled monitoring, the agricultural cooperative shall be given one month prior notice. If there is a suspect that the agricultural cooperative violates the requirements of Georgian legislation, the Chairman of the Agency instructs the authorized persons to conduct unscheduled monitoring. If the monitoring shows that the legal requirements are not complied with, the cooperative status is terminated. 
Main goal of the Agricultural Cooperatives Development Agency is to offer the farmers such mechanisms that would promote successful operation and long-term development of the cooperatives and this implies creation of the new jobs, introduction of advanced technologies, land consolidation, growth of agriculture and export potential of the country.

As of 1 January 2017, in Georgia, there are registered 1586 agricultural cooperatives distributed by the regions as follows (See Fig. 1): Kakheti - 156; Kvemo Kartli - 224; Mtskheta-Mtianeti - 86; Shida Kartli - 119; Samegrelo - Zemo Svaneti - 127; Guria - 53; Adjara - 155; Samtskhe-Javakheti - 358; Imereti - 124; Racha-Lechkhumi - 132; Tbilisi $-52^{3}$. In Racha-Lechkhumi and Kvemo Svaneti regions the cooperatives are distributed most uniformly, while their distribution is most uneven in Samtskhe-Javakheti region. Here the cooperatives mostly produce the potatoes.

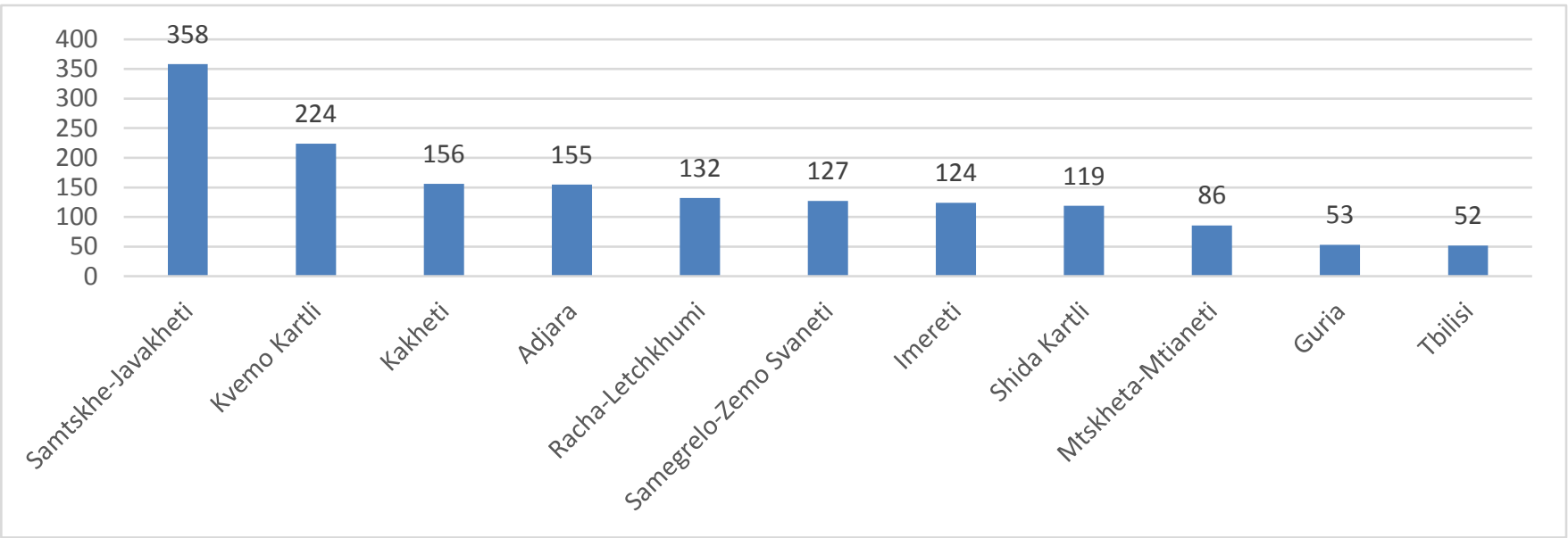

Fig. 1 Number of agricultural cooperatives by the regions of Georgia as of 2017

The survey, within the scopes of our study, showed that for the cooperatives operating in Georgia inn year 2017, the most important benefits included high incomes, production growth, employment, improvement of the products' quality, improvement of availability of the raw materials, supplies, infrastructure and market.

In studying of the agricultural cooperatives management process, we have applied qualitative research methods, in particular - the interviews and focus group meetings conducted for problems identification. In the process of research the information was collected about the following issues: management organizational structure, communication and decision-making process, organization strategies, professionalism and qualification of the employees, development of the staff potential.

Among the agricultural cooperatives, the bee-keeping, dairy production, hazelnut production and viticulture cooperatives the most widespread ones. The stratum of

\footnotetext{
${ }^{3}$ Agricultural Cooperatives Development Agency, http://acda.gov.ge/index.php/geo/static/118
} 
winemakers with wineries equipped with low capacity though state-of-art materialtechnological basis, with adequate raw materials supply is formed in Georgia. Wines produced by them are distinguished with fine quality and they are successfully sold at domestic and foreign markets [Keshelashvili G. 2016].

Cooperative Darcheli, established in 2015, in village Darcheli, is a hazelnut producing cooperative with 516 members, mostly engaged in primary hazelnut production and processing. The production cycle includes hazelnuts production, storage, removal of the shells and drying. If this cooperative was formed as the second level integrated cooperative enterprise, it would include hazelnut production, warehousing, drying, shelling, roasting, grinding, packaging and sale.

Based on information collected through interviewing of the cooperatives in various sectors there were identified the following positive outcomes resulting from development of agricultural cooperatives in Georgia: after association the farmers were able to manufacture the end products and deliver them to the consumers; the products range increased, the sphere of the cooperatives activities expanded and products' quantity and quality improved; the farmers gained better availability of market, the cooperatives produced marketable goods and they were able to distribute them through network of stores.

The research identified the following factors affecting cooperatives' management: farmers' education level, scope of the assets owned by the cooperative members, stability of the legislative environment, specific nature of the cooperative's activities and business management skills.

Lack of experience is a typical problem. The cooperatives are mostly managed by the general meeting, it elects the management board and the latter board elects the chairman. Frequently the chairmen have no leadership and management skills. The farmers have no long-term vision, most of them are oriented to one-year yields and they are not able to develop their economies in a consistent manner. General lack of the highly qualified professionals - the accountants, finance managers and specialists in agriculture is the problem for effective operation.

The main problem for sustainable development of the cooperatives and improvement of their effectiveness is the size of cooperatives. Most of the existing cooperatives are of "family" type. Most of the cooperatives were established for the purpose of gaining funding from the state and trust to the idea of cooperation and attraction of the new members is still very low. In Georgia, numbers of cooperative members are quite low. Most of the cooperatives have 3 or 5 members to meet the minimal legal requirements and due to this, the cooperatives earn low incomes and they are not the promising ones, in economic 
respect. The cooperatives and their members are mostly focused on the short-term benefits as they have no sufficient assets for business development.

The main source of information for the cooperatives is the local information and consultation centers. They provide information about ACDA programs, as well as various state and international assistance (see Fig. 2). Cooperative members receive information mostly through group meetings, booklets, press and TV. Only few of cooperatives can gain information from internet.

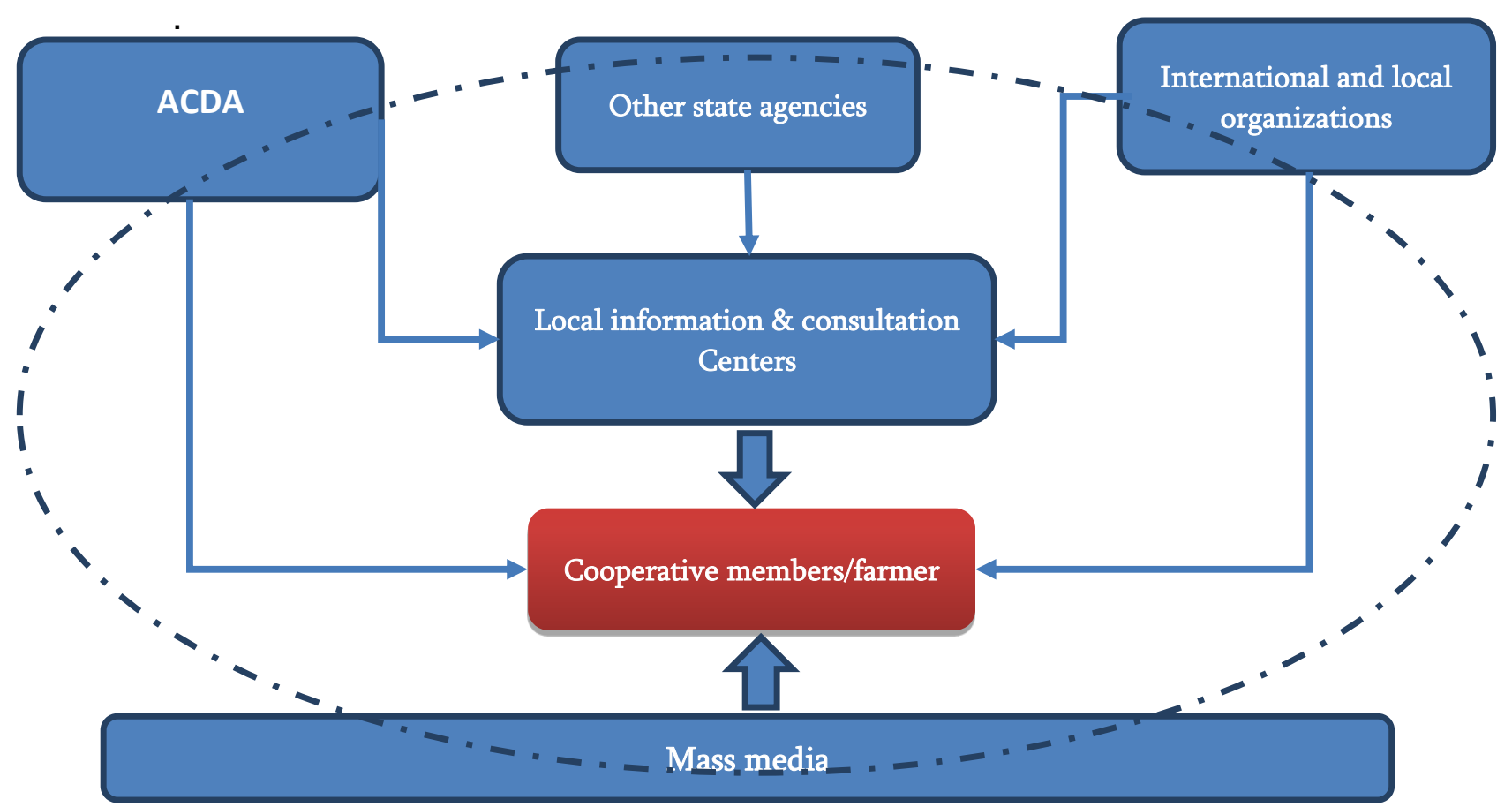

Fig. 2 Information channels used by the agricultural cooperatives in Georgia

Permanent re-training of the personnel employed by local consultation \& information centers is of great significance, as well as providing relevant knowledge and information to them, conducting of information campaigns in mass media, whether this is radio or television. These communication instruments are of particular significance for demonstration of the strengths of cooperation. Wide spreading of information about successful cooperatives is necessary. This would significantly improve the farmers' motivation. In addition, such approach can be used to interest the young people as well. It is recommended to gain support of the state and investors in introducing the ERP systems to small and average companies [Seturidze, R. (2016)]

Decision-making process in the cooperatives is quite difficult. Cooperative is a bureaucratic organization. It is managed by general meeting. It elects the managing directorate from the cooperative members. The cooperative is founded by joint decision 
of the members. Each of the cooperative members has one vote, irrespective of their share. Therefore, to make decision, the members require consensus.

In many cases the agricultural cooperatives have no formulated mission, goal and objectives. They are mostly founded for short-term benefits (to receive machinery, grants and other benefits). Influence of the traditional agricultural practices is significant as well. The farmers basically rely on the experience of previous generations, with little attention to the innovations. Application of the legal regulations related to the products quality in practice is a serious problem for the cooperatives.

Population produces agricultural goods with the traditional knowledge. They have no information about modern production technologies to improve productivity and goods quality. Industry trainings are especially needed. Emphasis should be made on delivery of knowledge of modern technologies and their practical application. Actually, most of the farmers have no any knowledge about agricultural business management, planning, profitability evaluation, financial calculations and business-related issues.

It should be noted that a wide research gap referring to the agricultural sector still exists. In agriculture, compared to other sectors of economy, financial management is strongly determined by unique determinants of agricultural production that are described in literature on agricultural economics/finance and farm management (Pawlowska-Tyszko, Soliwoda, 2016).

Development of science is increasingly focused on small, medium and large enterprises, on the economic and social motives and future trends of the development of the country (Keshelashvili, Jibuti, 2015).

\section{Process of Value Chain Management in Agribusiness}

$95 \%$ of the employed in the agriculture sector are small farmers producing very small quantities, so that they cannot compete with the suppliers of imported goods. In 2013, Georgia started to provide active support to formation and development farm cooperatives. In March 2013, the European Union and Georgia have signed the agreement on implementation of the European Neighborhood Program for Agriculture and Rural Development (ENPARD). Euro 52 million is allocated for the program and it is intended to ensure agricultural production growth and poverty reduction in rural areas of Georgia. One of the ENPARD objectives is development of business-oriented cooperatives that would assist small farmers in production development.

Generally, agricultural cooperatives can be divided into two key types. Production cooperatives where the cooperative members jointly produce the goods; they jointly own the production factors (lands, buildings and structures, equipment; mechanization etc.) and jointly use them. Service cooperatives are most widespread cooperatives all over the world. In the associations of such type the members do not consolidate the properties 
and production factors. The cooperative allows its members to procure the production factors at relatively low price (while before, each of them, individually created retail demand, after cooperation they create the wholesale demand); consolidate the products, process them and sell jointly; perform joint marketing activities; receive sectoral consultations and etc. (Jibuti, 2017).

Development of small farming can significantly contribute to socio-economic development and improvement of living conditions for a large number of population in Georgia. Nowadays, there are mostly small-scale farms in the country and they mainly produce only for self-consumption. In fact, population of the country consumes more imported goods than it produces. (Kharaishvili, 2016).

Population produces agricultural goods with the traditional knowledge. They have no information about modern production technologies to improve productivity and goods quality (Keshelashvili, 2017).

In Georgia, most small producers of agrarian goods face such problems as gaining desirable share of profit distributed over the entire value chain; production of high quality goods with available seeds, fertilizers and chemicals; low access to the financial resources for performing agricultural works in due time and seasonality of cash flows characteristic for their activities; problems of transportation of the produced goods that are frequently dealt with through sale of the products to the middlemen at very low prices.

Regarding the value chain management is organized union of the producers, merchants, processors and raw materials / service suppliers for improvement of productivity, the value chain participants should make attempts to improve and maintain competitiveness based on innovations. ,They must be able to use various competitive strategies and establish themselves in the global environment" (Chokheli, 2016). Participation of the commercial partners in the value chain should contribute to costs reduction and effective performance of business. ,,It allows clarification of the costs structure and improve the company's competitiveness through costs reduction/ Purpose of this method is to reduce not only internal activities costs but also reduce the costs on account of the suppliers, through offering them the forms of relations that ensure growth of the profits" (Chokheli , 2014).

Availability of the advanced technologies, information, capital, would help them in use of the innovative production techniques and effective marketing management, as a result, they will be able to supply high quality goods to the consumers.

Summarization of the research results and analysis of the international experience showed that while individually working small farmers are unable to gain profits from sale of their products, the farmers working collectively, who have established powerful organizational links in similar production in a form of cooperatives, are better able to take advantage of market opportunities and mitigate negative outcomes of the crisis situations. 
Naturally, the farmers can establish the cooperative enterprises. In addition, the primary production cooperatives can establish the new entities in a form of the second-level cooperatives allowing tightening of the value chain, costs reduction and improvement of profits.

For example, production of Georgian hazelnuts is a diverse and complex business significantly contributing to economic development of the country's regions. Georgia is $4^{\text {th }}$, among 5 leading hazelnut producers in the world, after Turkey, Italy and USA with 32.900 tons of average hazelnuts output per year. Among Georgian regions, SamegreloZemo Svaneti, further, Guria and Imereti produce highest quantities of hazelnuts among Georgian regions. Most part of the produced hazelnuts is sold at market through middlemen; variation of prices for Georgian hazelnuts depends on the yields in Turkey, the main hazelnut supplier at world market. Because of fragmentation and small-scale production, the hazelnut producers supply the hazelnuts of different varieties; hence, they yield the harvests in different period and apply different technologies of production and warehousing thus significantly impacting the products' quality. In our opinion, positive attitude of the consumers to Georgian food products is a significant investment for further development of the local companies producing and distributing food" (Mghebrishvili, 2018).

In case of hazelnut producing farmers in Georgia, the hazelnuts are sold at regional markets by the farmers, where the product is bought by the consumer directly (relatively rare case) or at the farm, to the middlemen, procuring the products from each of the farms separately, gain the quantities profitable for sale and performs the resellers' function (see Fig. 3). From these activities they gain the profits that are frequently much higher than that of the original producer.

In case of hazelnut producing cooperatives single link of the value chain unifies several subjects. Before sale the product is subject to numerous processes: procurement of the materials for production, hazelnut growing, harvesting, drying, trade in raw materials, cleaning of the raw materials, shelling, roasting, grinding, vacuum packing, transportation, sale at the European or Asian markets. This case allows tightening of the value chain, as the cooperatives need fewer middlemen or relations with the collection centers to sell their products (see Fig. 4). Cooperatives perform relatively greater part of the activities and hence, most part of profit margin is maintained by the cooperative. 


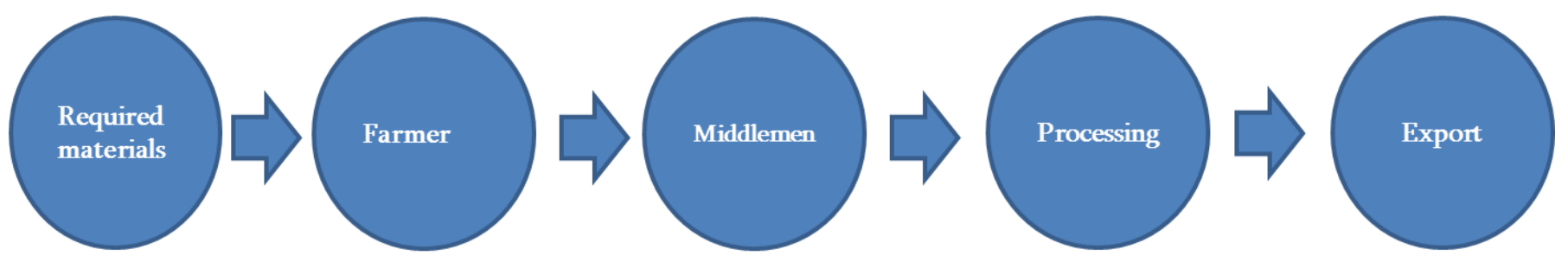

Fug. 3. Hazelnut value chain for the farmers

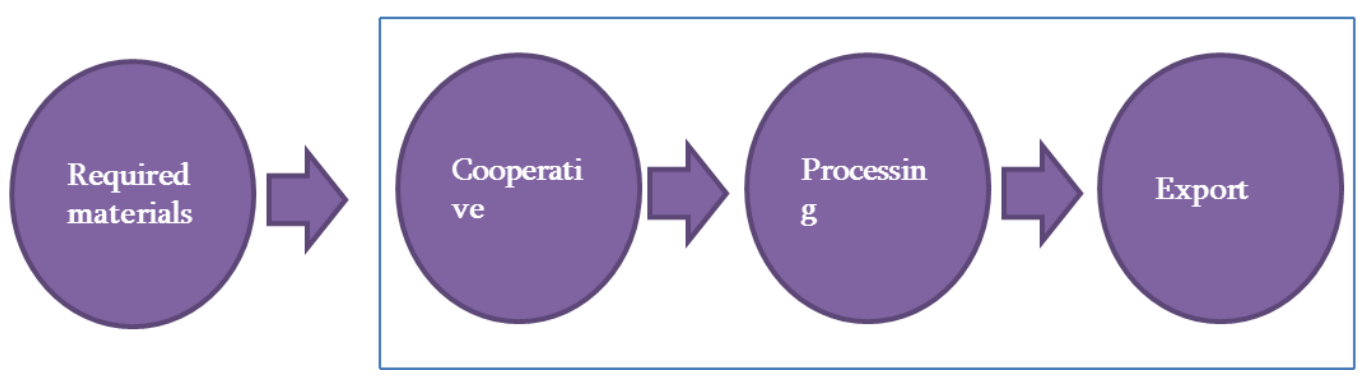

Fug. 4. Hazelnut value chain for the cooperatives

Regarding the above, it is clear that in case of cooperation, it is possible to unify the cooperative, processing and export chain into single chain link, thus significantly reducing the value chain.

In Georgia, one of the key sectors of agribusiness is livestock and dairy production. For last 10 years the dairy production growth achieved $10 \%$. Nevertheless, local production cannot meet the domestic demand and the country depends on the imports. The main challenge for sector development is low productive varieties. Productivity of animals owned by the farmers in Georgia is five times lower than that in the Ukraine and ten times lower than in the USA. The largest dairy producers in the world are: USA ( 91.3 billion $\mathrm{kg}$ ). India (60.6 billion kg), China (35.7 billion kg), Brazil (34.3 billion kg) and Germany (31.1 billion $\mathrm{kg}$ ). In the most of them, the farmer is the main link of the value chain. 
In Georgia, milk, dairy products and meat are mostly produced by the rural household economies and they consume about one half of their products and sell the other half. Here, the main participants of the value chain include: farmers producing milk and dairy products, middlemen and open agrarian markets where the sellers deliver the dairy products to the end users and suppliers of the goods/services required for production of the raw materials (veterinary drug stores, veterinarians etc.), see Fig. 5.

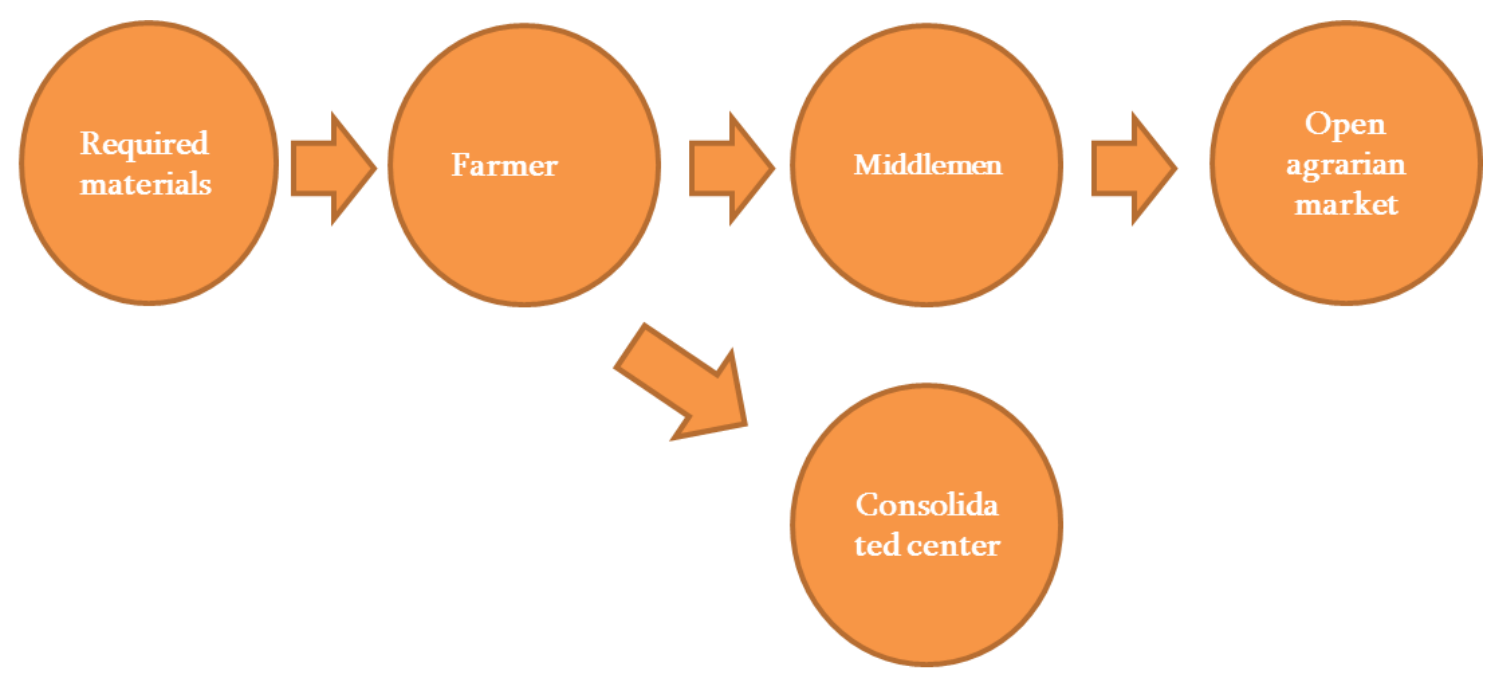

Fig. 5. Dairy products' value chain for the farmers

Currently, in Georgia, 43 dairy cooperatives are registered. Cooperation unifies several chains: farmers, collectors and milk processors unified in the cooperative. The cooperative unifies the farmers collecting the dairy products and delivering them to the processing enterprises, though, it should be noted that regarding the specific nature of the sector, the main challenge for such unification is production of the products of uniform quality, establishment of the internal standards and complying with the by the farmers (see Fig. 6).

Though in the interlinked value chain the independent producer manufactures the products according to the buyer's orders, within the scopes of the permanent relations, the management form is developed where the small farmers become dependent on the large, leading companies. Supply chain significantly impacts the process of value chain formation, as it forms the structure of supply of the services/ materials required for raw materials production through creation of the added value. Conception of the supply chain is similar to the value chain. Supply chain includes the functions of supply of the war materials and goods/services to the individual producers and their marketing. Hence, supply chain management is the most significant part of business management, it is more about logistics than about market development and directly impacts profitability of production. 


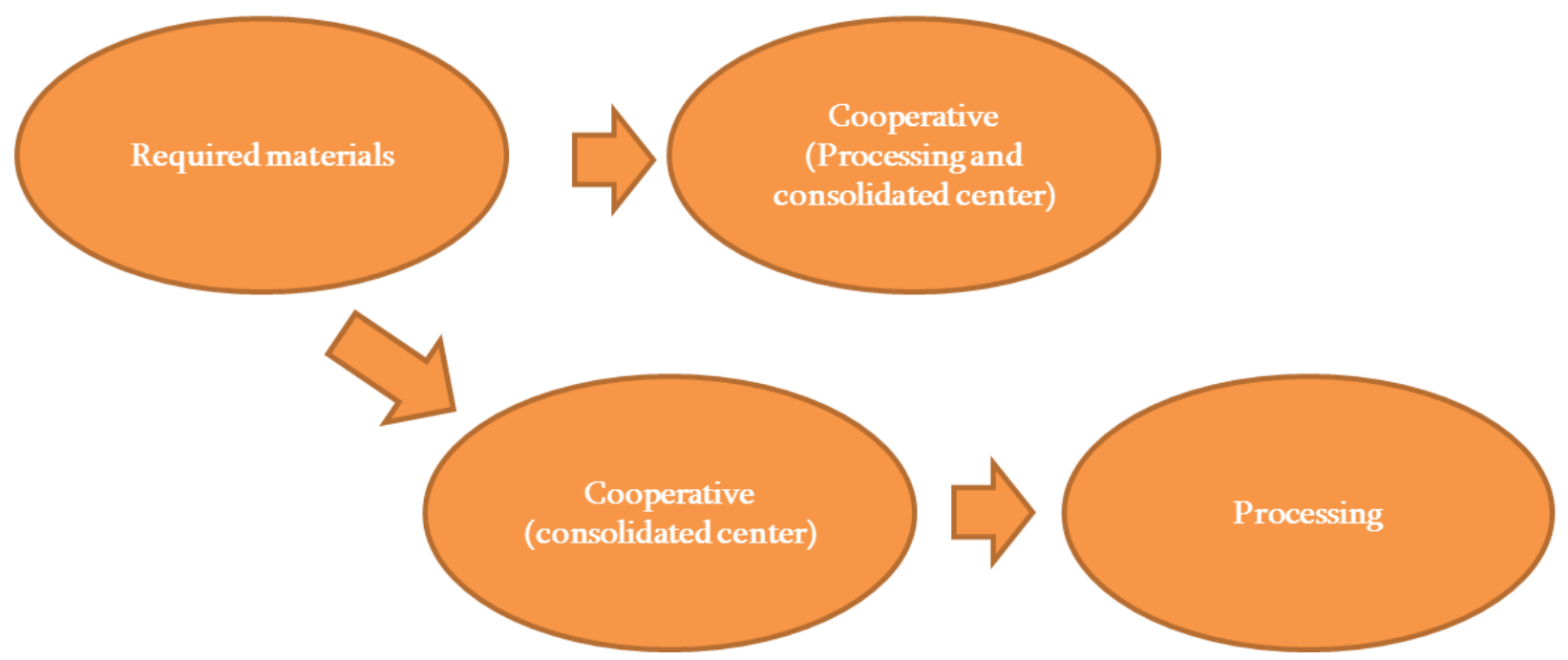

Fig. 6. Dairy products' value chain for the cooperatives

In this respect, it is significant to analyze honey supply chain in Georgia. Beekeeping is one of the growing sectors of Georgian economy. According to the data of the Department of Statistics, Georgia produces 2.1 thousand tons of honey. Georgia exports honey mostly to Libya, United Arab Emirates, Saudi Arabia, Iraq, Lebanon, China, Turkey, Azerbaijan, Russia and Republic of Korea. Some farmers sell the honey through direct sale while the most of them use the middlemen (see. Fig. 7).

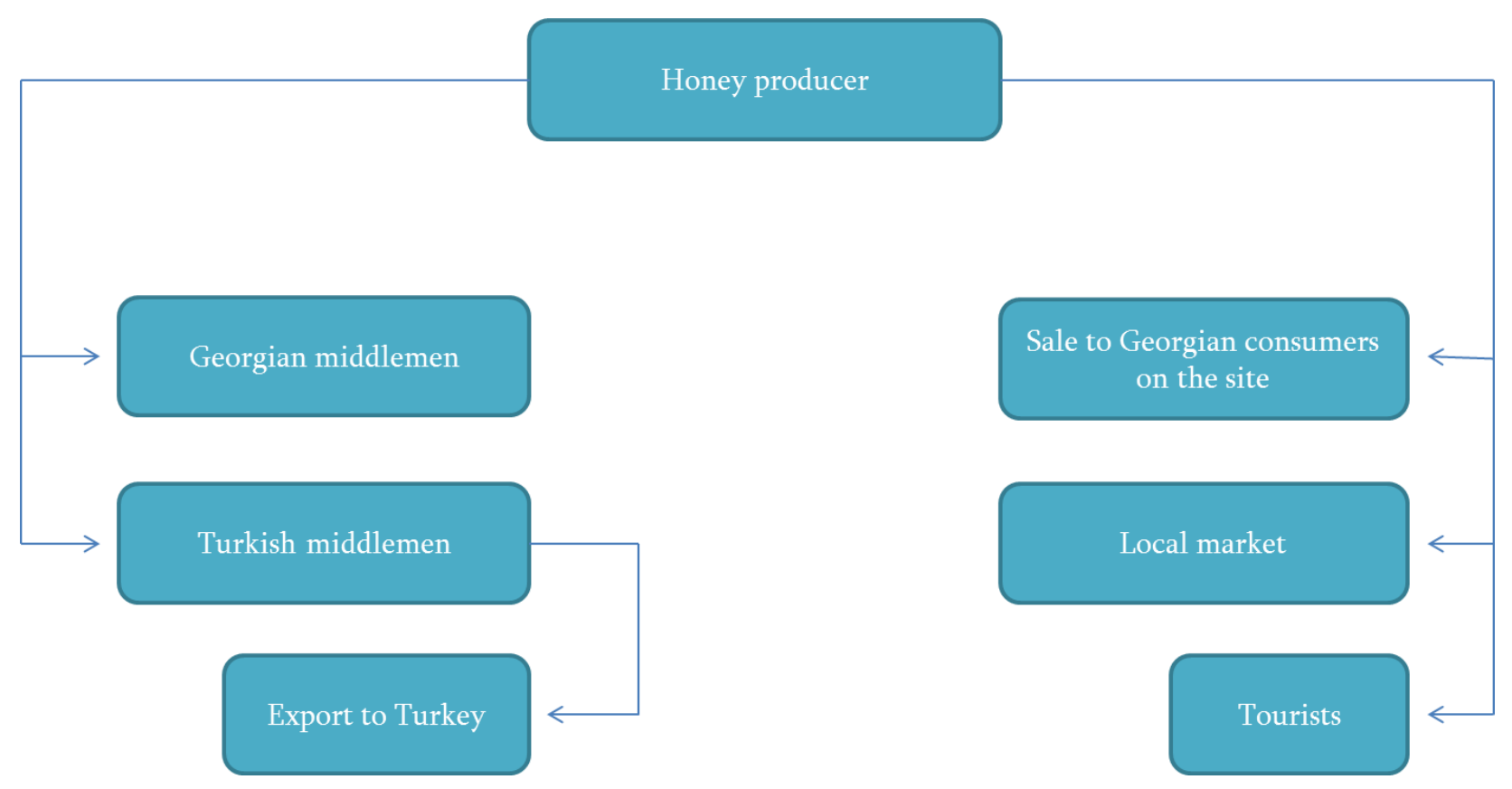




\section{Fig. 7. Honey supply chain in Georgia}

Currently, 74 honey producing cooperatives are registered in Georgia, with direct links with the local supermarkets and hypermarkets. They do not need the middlemen, they perform the middlemen function themselves and hence, their profit margin is higher and it is distributed to the cooperative members. Fig. 8 depicts value chain of he honey cooperative in Georgia.

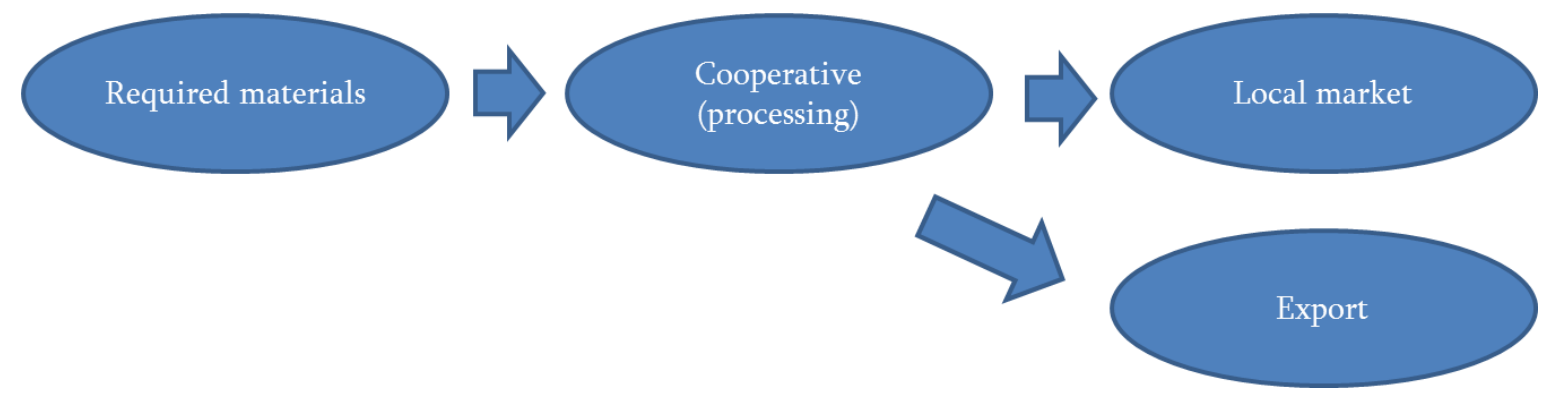

Fig. 8. Honey cooperative value chain in Georgia

Unification of farmers in the cooperatives improves their competitiveness and allow better availability of the materials required for production of agricultural raw materials, services and markets, as well as ensure direct links with their consumers and hence, gain direct information about the characteristics of their demands and develop the products and services on its basis.

Development of cooperation would contribute to improvement of the value chain and the consumers' satisfaction, as the products' end price can be reduced through reduction of the number of participants at each stage of the value chain. In addition, the cooperative members will have the opportunity to gain much higher profits from sale of the end products than they would gain in case of individual work through sale of the primary production outputs to the middlemen. Creation of the entire cycle of agricultural goods production, processing and sale in the cooperatives, where the product manufacturers will receive increased revenues from sale of the products without any intermediate cycles should be supported (Keshelashvili, 2017).

Research showed that most cooperatives operating in Georgia have no sufficient knowledge for better planning, production and value chains management, forecasting of the proposed results an evaluation of their achievement.

\section{Conclusions and Recommendations}

Analysis of the agribusiness value chain management in Georgia showed that: 
- The farmers still use traditional methods in production, without any innovations, their profits are very low, especially at the stage of primary production;

- Farmers have no long-term vision and they are mostly oriented towards annual business plans only, without relying on the material documents;

- Farmers lack professional knowledge and experience in marketing, this prevents their integration into the value chain;

- Forming of the cooperatives would allow the farmers to reduce the costs at various stages of value chain and take more advantages from the market opportunities though better involvement into the sales process;

- Establishment of the second and third level cooperatives together with the first level ones would further tighten the value chain, reduce the costs and improve the benefits of primary producers, thus contributing to further development of their activities.

For the purpose of improvement of value chain management in agribusiness, we regard that implementation of the following measures would be of significance:

- Improvement of the farmers' qualification, through their professional re-training, for their meaningful integration into the cooperatives value chain;

- Support to formation of the cooperatives oriented towards long-term goals and strategies so that their members were oriented towards sustainable development of the farm economies and commenced organized management of their activities;

- Long-term strategic planning of the state support programs based on the specific indicators taking into consideration the strategic goals of the agricultural cooperatives development (Keshelashvili, 2017);

- Stimulation availability of the credit and insurance systems, providing better opportunities for introduction of the new technologies and effective management of the agrarian terms;

- Stimulate creation of large cooperatives (e.g. with 50 members) instead of the ones with 3-5 members, first-level cooperatives should be formed with expanded functions (Keshelashvili, 2017);

- In implementing the relevant regulations by the government of Georgia for the purpose of approach to the EU legislation in the sphere of food safety, stimulation of the farmers' unification unto the cooperatives and support to better visibility of the cooperative products.

\section{References}

Rural Development strategy of Georgia 2017-2020

Agriculture of Georgia, Statistical Publication, National Statistics Office of Georgia, Tbilisi, 2017

http://geostat.ge/cms/site images/ files/georgian/agriculture/2016\%20wlis\%20soflis\%20meurneoba.pdf 
Chokheli, E. (2016). The impact of the competitive strategy on the success of wine companies (The Case of Georgia), Proceedings of 24th international academic conference, International Institute of Social and Economic Sciences, Barcelona.

http://www.iises.net/proceedings/24th-international-academic-conference-barcelona/table-ofcontent/detail?article=the-impact-of-the-competitive-strategy-on-the-success-of-wine-companiesthe-case-of-georgia-

Chokheli, E. (2014). "About modern methods and instruments of Strategy analysis", Proceedings of International Scientific Practical Conferences, Sokhumi State University.

Chokheli, E. (2015) Role of the Organizational Design in the Company's Success. European Scientific Journal, 91.

Chokheli E, Narmania D. (2015) Information Tecnnologies In Management And Prospects To Improve Their Use By Georgian Companies. Int J Recent Sci Res, 6(9), 6515-6518.

Dadiani L. (2015) Building Farmer Cooperatives in Georgia: Supporting smallholder farming in the postsocialist context.

Facilitate Sustainable Linkages of Agricultural Cooperatives with Market Players and Extension, Evoluxer S.L International Consulting, 2017.

Keshelashvili, G. (2017). Characteristics of Management of Agricultural Cooperatives in Georgia, Proceedings of 32nd International Academic Conference, 27-30 June, Geneva, p.132- 143.

http://www.iises.net/proceedings/32nd-international-academic-conference-geneva/table-ofcontent/detail?article=characteristics-of-management-of-agricultural-cooperatives-in-georgia

Keshelashvili, G. (2016). General Strategies of Georgian Winemaking Companies' Management in the Conditions of Integrated Development, 23rd International Academic Conference, 27-30 April, Venice, Italy.

http://www.iises.net/proceedings/23rd-international-academic-conference-venice/table-of-content

Keshelashvili, G. Jibuti M., (2015). The Commercialization of Ideas and Customer's Needs in the Georgian Market, 15 $5^{\text {th }}$ International Academic Conference, 14-17 April, Rome, Italy.

http://www.iises.net/proceedings/international-academic-conference-rome/front-page

Kharaishvili, E. (2016). Small Farm Diversification Opportunities in Viticulture-Winemaking Sector of Georgia", World Academy of Science, Engineering and Technology, International Science Index 113, International Journal of Social, Behavioral, Educational, Economic, Business and Industrial Engineering, 10(5), 1376 - 1379.

Looking Ahead in World Food and Agriculture Perspectives to 2050, Food and Agriculture Organization of the United Nations, 2011.

Mghebrishvili, B. (2018). Some Aspects of Social Marketing Development in Georgia, IV International Scientific and Practical Conference "Strategic Imperatives of Modern Management", 19-20 April, Kiev.

Mikiashvili, N., Lobzhanidze, N.(2016). Important Aspects of the Macroeconomic Stability and Competitiveness of a Small Open Economy. CASE-Center of Social and Economic Research. 25th Anniversary conference. 17-18 November, Warsaw, Poland

Pawlowska-Tyszko J., Soliwoda M., (2016), Agricultural Accounting Systems Supporting Farm Financial Management - The Case of Polish FADN, Proceedings of the $3^{\text {rd }}$ Business \& Management Conference, Lisbon. https://doi.org/10.20472/BMC.2016.003.016 
Seturidze, R. (2016). Role of the ERP systems in the successful management of Georgian companies. Book of Abstracts Business Systems Laboratory Review. ISBN 9788890824234 . Vilnius, Lithuania.

The Role of Family Farming in the Sustainable Development of Agriculture Sector and Poverty Reduction, ISET, Tbilisi, December, 2014.

Toloraia I., Angelovski D., (2011), Assessment of the constraints faced by selected farmer organizations and legal entities owned by small scale farmers in Georgia to achieve their potential.

Tvalchrelidze A. Silagadze, A. Keshelashvili, G. Gegia D. (2011). Georgia's Social Economic Development Program. "Nekeri", Tbilisi.

www.ifsdeurope.com/getdoc/34/Georgia\%20social\%20economic\%20development\%20program.pdf Jibuti, M. (2017). Key Issues of Competitiveness of Agricultural Sector (The Case of Zemo Svaneti Region), $32^{\text {nd }}$ International Academic Conference, Geneva, 27 June, 2017. ISBN 978-80-87927-39-7, IISES. Official web-page of Ministry of Agriculture of Georgia, http://moa.gov.ge

Official web-page of National Statistics Office of Georgia, http://geostat.ge/

Official web-page of Agricultural Cooperatives Development Agency, http://www.acda.gov.ge

Official web-page of International Co-operative Alliance, https:/ica.coop/ 